\title{
RELATIONSHIP BETWEEN FAMILY OWNERSHIP, AGENCY COSTS TOWARDS FINANCIAL PERFORMANCE AND BUSINESS STRATEGY AS MEDIATION
}

\author{
Enni SAVITRI \\ Faculty of Economics and Business, Universitas Riau, Jl.HR. Soebrantas Km. 12,5 Panam, \\ 28293 Pekanbaru, Riau, Indonesia \\ E-mail:enni.savitri@lecturer.unri.ac.id
}

Received 10 March 2017; accepted 23 April 2018

\begin{abstract}
This study investigates the relationship between family ownership, agency costs, financial performance, and companies' business strategies. The targeted population of this study were all 143 manufacturing companies listed on the Indonesia Stock Exchange (IDX) during 2007-2014. About 31\% (45) of these manufacturing companies are family companies. The hypotheses were tested using the partial least-square (PLS) method. Our findings reveal that the companies' business strategies are not affected by the family ownership. Family ownership and business strategies influence companies' financial performance. Agency costs influence business strategy and financial performance, and this shows that agency costs contribute to both the increase and decrease of financial performance. Business strategy mediates the relationship between family ownership and financial performance. This shows that family companies do not concentrate on financial goals but rather on the sustainability. Business strategy influences the relationship between agency costs and financial performance. This shows that funds can be redistributed in the course of business strategy planning, which will, in turn, improve the company's development.
\end{abstract}

Keywords: family ownership, agency costs, financial performance, business strategy.

JEL Classification: G32, G34.

\section{Introduction}

Formation of a company purports to improve the shareholders' benefit. It is depicted by the company's financial performance. The company's financial performance is obtained from accounting information in the form of financial reports which convey the actual condition. Sound financial performance is essential for the stakeholders such as creditors, suppliers, employees and clients. Financial performance is an achievement of a company in a certain period, which reflects the level of the company's financial soundness (Sawir 2005). A sound financial performance can be achieved by control from the owner and the director.

Companies in Indonesia are mostly characterized by family ownership in which the top management positions, whether it is the board of commissioners or the board of directors, are filled by family members. This may lead to agency conflict between the owners, managers and shareholders (Wiranata and Nugrahanti 2013). The separation of cash-flow and control rights occurs because of ownership concentration of public companies. This phenomenon is in place due to the shareholders being able to command the company either at once or indirectly. It is rightful that a number of companies in Indonesia are controlled by the same shareholders. This happens because some ownership mechanisms, especially pyramid ownership and cross ownership, are commonly found in developing nations, including Indonesia, and some developed countries through other companies.

With the cut-off of control right about $20 \%$, the number of companies with concentrated ownership is $77 \%$. Ownership concentration occurs not just in Asia, but also in Europe. La Porta et al. (1999), Claessens et al. (2000) and

\footnotetext{
Copyright $\odot 2018$ The Authors. Published by VGTU Press.

This is an Open Access article distributed under the terms of the Creative Commons Attribution License (http://creativecommons.org/licenses/by/4.0/), which permits unrestricted use, distribution, and reproduction in any medium, provided the original author and source are credited..
} 
Faccio and Lang (2002) show that public company ownership concentration occurs in almost all countries in Asia, Europe, America and Australia. The 20\% voting rights in family companies still have significant influence in policy making, which is the power to participate in financial and operating policy making in an economic activity, but it does not control or joint control the policy. The significant influence can be proved by representation in the board of directors and the board of commissioners, participation in the process of policy making, including dividend and other distributions, material transactions between entity and investment, managerial personal exchange and provision of principal technical information (SFAS 15 2013).

A family-concentrated company applies the best business strategy for the sake of the company's business development. The right strategy will lead to improvement and maximum results in the achievement of financial performance in the family company. Therefore, business strategy cannot be separated from family companies since entrepreneurship will promote innovation and brilliant ideas for developing the family companies and surviving the competitions with other family companies or non-family companies.

Agency problems may still be found in a family company which involves the controlling party (the family) and the non-controlling party (non-family). Agency costs would be needed to minimize the agency problems. Companies which are managed by families will have the agency costs equal to zero (Litz et al., 2004). According to studies by Jensen and Meckling (1976), Fama and Jensen (1983), Ang et al. (2000), if the level of agency costs is zero, the cost incurred by the company can be distributed to implementation of strategy by the company.

Strategic planning is useful to achieve the vision and mission of the company which show that the desired targets are accomplished. Business strategy is interpreted as the ways that a company uses to compete, including accomplishment, achievement, and maintenance of competitive advantage in its industry (Haryadi 2008). Family companies prefer defender strategy while other companies prefer prospector strategy. The compatibility of the preferred and implemented strategies contributes to the improvement of the companies' performance (Lena 2007).

Firm with high Family ownership has a unique agency problem which is associated with shareholders who also invest in the company. Family members who occupy top management positions should not only emphasize their priority on the best interest of their family, but they should also give their attention to other shareholders within the company.

With the occurrence of agency problems, a company tries to minimize it by providing agency costs. Higher agency cost reflects higher complexity of agency problem in the company. This causes instability in the company operational activities and it has a negative impact on the company's performance (Astuti et al. 2015).

The family-concentrated companies have the opportunity for the successor generations to express their ideas in the companies' activities. The planning is originated from a careful planning in the implementation of the strategy, either long term or short term business strategies, which supports the achievement of the companies' vision and mission.

Further, the implementation of a business strategy by a family-concentrated company will influence the company's performance. The family-concentrated companies usually have bright ideas which are desired to be applied in the strategic planning of the companies. The selection of the business strategy of family-concentrated companies is highly dependent on either differentiation or low cost. The business strategy will play a significant role in the companies' ability to gain market share. Therefore, it will influence the companies' performance.

Some previous studies emphasized analysis on the aspect of a company's performance (Anggraita 2013; Warsini and Rossieta 2013; Astuti et al. 2015), agency costs (Layyinaturrobaniyah and Fitriyana 2014), and value of the company (Villalonga and Amit 2006). Different from other previous studies, this research tests the influence of family ownership and agency costs on financial performance with business strategy as the intervening variable. Family-concentrated companies pay great attention to the implementation of business strategy because it can influence their performance. It is because the selection of the right strategy makes the companies gain the desired market share. In addition, family companies are definitely capable of minimizing agency costs. Low agency costs allow the companies to distribute funds to business strategy which supports their performance.

This study focuses on family ownership where the interaction of business strategy and agency cost can influence financial performance. Majority of companies in Indonesia are family controlled companies which are owned by families who are having full control on all the companies' business strategies. In family ownerships agency problems still occur. The selection of agency problem is one way to reduce the problems faced. Seven hypothesis related to relation between family ownership, agency costs, financial performance and company business strategy are examined, namely family ownership influences the firm's business strategy, family ownership influences the firm's financial performance, agency costs influences the firm's business strategy, agency cost influence the firm's financial performance, business strategy influences the firm's financial performance, business strategy influences the relationship between family ownership and financial performance, business strategy influences the relationship between agency costs and financial performance. 
This study examines a sample 143 manufacturing companies listed in Indonesia Stock Exchange (IDX) from 2007 to 2014. The results of the study is Family ownership influences company financial performance, Agency costs influence business strategy, Agency costs influence financial performance which shows that agency costs contribute to the increase and decrease of financial performance, Business strategy influences financial performance, The business strategy is able to influence relationship between family ownership and financial performance. Business strategy influences the relationship between agency costs and financial performance, and Family-concentrated companies do not influence business strategy used by the companies since uniqueness and company characteristics are important in applying the strategy.

\section{Literature review and hypothesis development}

Jensen and Meckling (1976) define an agency relationship as a contract in which one party acts as the principal who hires other people as the agent to provide certain services according to their needs, including the delegation of power to make decisions to the agent. If both parties in this relationship make the most of their own utilities, there can be strong reasons to believe that the agent will not always do the best for the owner. The general problem in this theory is how to make the agent act in order to maximize the owner's prosperity.

The relationship between shareholders and managers in a company is in line with the definition of agency relationship which separates ownership from managerial control. Separation means that managerial function and ownership function are handled by two different parties. The management done by the managers needs control and supervision from the shareholders as the owner of the asset (Jensen and Meckling 1976).

The agency theory of firms posits that the separation of ownership and control in public companies will allow managers to work on interest above the interest of the shareholders (Jensen and Meckling 1976). Historically, the separation of ownership and management has become an important principle in company governance. Indirect relationship between the owner and management has close relationship in company management. As long as the owner is the only shareholder of the company, he or she will follow the company's development and supervise the company management as happened in a family company (Astuti et al. 2015)

According to Madison (2014), the theory of agency specifically is related to structural behaviours and perspectives. This theory states that the by giving an opportunity to the agent, he or she will act selfishly and ignore the interest of the principal. Therefore, principal will implement structural mechanisms which supervise the agent to restrain opportunistic behaviours and balance the relationship between the agent and the principal.

There are two types of agency conflict. The first one is a conflict which happens in companies with dispersed ownership. In this case, the manager (the agent) acts for the agent's own interest without paying attention to interest of the shareholders (principal). The second type of agency conflict is a conflict which occurs in concentrated ownership companies such as family company. In this case, the conflict occurs between the controlling shareholders (family) and non-controlling shareholders (non-family). This type of conflict happens when the family as the major shareholder controls the company and makes decisions without considering the non-controlling shareholders. Board of directors and board of commissioners which come from the family want to control the management as they pleased. Therefore, they make decisions which are advantageous for them (the agent) without considering the minor shareholders (the principal).

\subsection{The influence of family ownership on business strategy}

The controlling party (family) is the representative which will run the companies' activities. According to Anderson and Reeb (2003), a family firm is every company which has dominant shareholders. Morck and Yeaung (2004) define family company as a company which is run based on heredity or inheritance from people who previously run the company or a family who obviously inherits the company to the next generation.

Family-concentrated companies have entrepreneurship and innovation (Poza et al. 1997). The top management will introduce innovations and come up with bright ideas for achieving the vision and mission of the company. Business strategy is an essential part of a company. Business strategy can improve the company's business performance and make it more competitive.

The selection of a business strategy in family-concentrated companies pays a lot of attention to the strengths and weaknesses of the strategy. One way of exploring business strategy proves that the company tends to do a great variety of business extensively (Warsini and Rossieta 2013).

Companies which are controlled by a family do not only aim for financial improvement (Moores 2009). Moores adds that family companies are concerned with long term continuity of the business so that the business strategy which has been designed by the company can develop according to the plan. However, special characteristic of family companies in deciding business strategy cannot directly determine a certain business strategy which is suitable with family ownership since the business strategy in family companies is 
dichotomous (Ibrahim et al. 2008). Referring to the description above, the hypothesis of this research is as follows:

$H_{1}$ : Family ownership influences the firm's business strategy.

\subsection{Family ownership and financial performance}

Achievement of a company in financial performance can give an overview of the company's financial condition in a certain period of time. Family companies are able to improve their performance by collaborating five competitive advantages, namely combination of ownership and control, reduced information gap, sustainable family shareholders, source of entrepreneurship and innovations, and investment efficiency. Therefore, this approach can influence family ownership to the company's performance (Chu 2011).

Family-owned companies usually allocate more than $30 \%$ of the profit for financial performance improvement. However, financial performance may decrease when family ownership increases. It is a result of conflict of interest among the family members which are disadvantageous for minority of shareholders. Nevertheless, the improvement of financial performance can be stable if the family is kept under a supervision to minimize expropriation; it will be beneficial for the family-concentrated companies (Shyu 2011).

Pressure to the company will cause institutional overlap, where a business institution is also a family institution at the same time which leads to a dilemma. The owner which is also the manager frequently puts the goal of the family before the business which decreases the level of company performance (Warsini and Rossieta 2013). Based on the description above, the hypothesis of the research is as follows:

$\mathrm{H}_{2}$ : Family ownership influences the firm's Financial Performance.

\subsection{Agency costs and business strategy}

Agency costs in a family company can be minimized if the company is under good governance which controls the relationship between the owner and the management (Astuti et al. 2015). When family members involved in the company, agency costs which are initially allocated for managers in top management can be minimized because the managers are the family members themselves.

Jensen and Meckling (1976) state that the sole shareholder (100\%) will have agency costs equal to zero. It is supported by Fama and Jensen (1983), who argue that agency problem between owner and manager happens because decision making and control are done by the same agent family members. It can minimize agency costs which are needed to supervise the decision.

The company's ability to minimize the agency costs is beneficial for planning the business strategy. The selection of business strategy will influence the share market of the company. Companies that choose to apply differentiation strategy aim to produce goods or services which considered unique and are directed to consumers who are relatively sensitive to price. On the other hand, cost leadership strategy emphasizes on the process of production of standardized products with low per unit cost for consumers who are sensitive to price (Porter 1980). Therefore, the hypothesis is proposed as follow:

\section{$H_{3}$ : Agency costs influence the firm's business strategy.}

\subsection{Agency costs and financial performance}

The theory of agency offers two options for the principal and the agent to avoid agency problems. Both of the options restrain opportunistic behaviour. The first option designs a governance structure which allows supervision and assessment toward the agent's behaviour. This structure includes reporting procedure, addition of management personnel or the main board of directors (Donaldson and Davis 1991). The second option designs a governance structure in which a contract based on the agent's behaviour to generate agency costs which is borne by the principal aims to watch and asses the agent's behaviour (Madison 2014).

According to agency theory, agency costs are not something that should be minimized by the company. Because of agency costs, it is expected that agents can benefit from shareholders. Therefor, the existency of agency costs $n$ the family company is expected to improve the performance of the company.

Agency costs of a company can be measured by using two alternative ratios, expense ratio and asset utilization ratio. In this research, expense ratio which reflects discretion managerial expense in spending the company resources is used as a proxy for the agency costs. The higher the discretion of managerial expenses, the higher the agency costs will be (Faisal 2005). Meanwhile, total asset turnover measures the agency costs based on the level of asset turnover and as a proxy for asset utilization. This ratio is used to measure efficiency of asset utilization by the management. The higher the ratio, the more productive the asset is used to produce value for the shareholder (Faisal 2005).

Family ties in family-concentrated companies can create unique agency problems, which can lead to conflicts commonly found in family companies. The conflicts can be caused by different perspectives among the founder of the company as the principal and the younger generation as the agent in running the business (Litz et al. 2004).

High agency costs in a company indicate poor management in managing operational costs. It is related to efforts to gain operational income and indicates management fraud which is concealed in the use of operational costs. It can lead to high agency costs and decreasing company performance (Layyinaturrobaniyah and Fitriyana 2014). Based on the description above, the following hypothesis is proposed:

$\mathrm{H}_{4}$ : Agency costs influence the firm's financial performance. 


\subsection{Business strategy with financial performance}

According to David (2011), business strategy comprises geographical aspect, acquisition, product development, market penetration, tightening, divestment, liquidation, and joint venture. Strategy allows organization to gain competitive advantages from three different bases, namely cost leadership, differentiation and focus. Porter (1980) calls these bases as generic strategies.

Tendency in selecting a business strategy will give benefit to financial performance of the company. It happens because the customers have interest on the offered product, so they will keep purchasing the product. In addition, the company's income will increase and it is in line with bright ideas applied by the family members involved in the company. Finally, all of them can give contribution to the company's business strategy.

Warsini and Rossieta (2013) find that the business strategy affects the company performance. Family companies definitely make a selection in achieving their desired business strategies. Lamin (2007) explores business strategies in an affiliated company which is controlled by a family in India and finds evidence that the affiliated companies tend to do extensive diversification and their business strategy determine the influence of resource-based business affiliation on performance. Referring to the description above, the hypothesis is as follows:

$H_{5}$ : Business strategy influences the firm's financial performance.

\subsection{Family ownership, business strategy and financial performance}

Family participation in a company can strengthen the company since family members are loyal and dedicated to the family company. However, the participation sometimes causes problems in managing family companies, especially in selecting a strategy to gain share market and focus to improve the company performance.

It is in line with Moores (2009) who argues that family companies do not only aim for financial goal but also for the sustainability of the company so that the business strategy can be fulfilled. Therefore, family ownership is supported by good business strategy in order to improve the company performance.

Conceptually, company financial performance measured by Return on Equity (ROE) is an ability to generate profit for the shareholders from own capital. Family company with relatively big portion of share definitely expects better return on equity growth. However, it is not in line with the expectation of increasing ROI, since large family ownership means that the share owned by the family is not followed by growth of financial performance which is measured by return on equity.
Emphasis on company as institutional overlapping in a family company in which a business institution is also a family institution leads to a dilemma. The owner which is also the manager frequently puts the goal of the family before the business which decreases the level of company performance (Warsini and Rossieta 2013). Based on the description above, the hypothesis of the research is as follows:

$\mathrm{H}_{6}$ : Business strategy influences the relationship between family ownership and financial performance.

\subsection{Agency costs, business strategy and financial performance}

Conceptually, low agency costs indicate less agency problems. This condition is expected to make the company performance more efficient compared to companies with high agency costs which indicate more agency problems. Dominant shareholding in family company will make management control more effective compared to other ownership structures, so the agency costs can be reduced.

Low agency costs allow more fund allocation on more compatible business strategy planning, which is expected to increase the company performance. Therefore, the influence of family will create varied business strategies (Lindow et al. 2010) and the accuracy of business strategies will contribute to the company performance (Lena 2007).

Companies with family-concentrated ownership will decrease agency problems between the owners and the managers so that it can create value of the companies. Therefore, it is based on good value and strategy which is compatible with resources. Referring to the description above, the hypothesis is as follows:

$H_{7}$ : Business strategy influences the relationship between agency costs and financial performance.

\section{Research methods}

\subsection{Population and sample}

The targeted population in this research were all $143 \mathrm{ma}-$ nufacturing companies listed in Indonesia Stock Exchange (IDX) from 2007 to 2014. Almost 31\% or 45 of the manufacturing companies are concentrated on family companies (IDX). The data were obtained from Capital Market Information Center which was issued by the Indonesia Stock Exchange, Bank of Indonesia, and Indonesian Capital Market Directory (ICMD).

\subsection{Operational definition and variables measurement}

This research involves three types of variables, namely independent variable, dependent variable, and intervening variable. The independent variable is family ownership which is measured by percentage (\%) of share owned by the family divided by outstanding shares (Faccio and 
Lang 2002). Agency costs are measured as the general and administrative operational expenses divided by total sales (Faccio and Lang 2002). The dependent variable in this research is financial performance which is measured by Return on Asset (ratio of net profits after tax to total assets) and Return on Equity (ratio of net profits after tax to total equity). The intervening variable in this research is business strategy which is measured by Premium Price Capability (PPC) obtained from gross margin divided by sales. If the value of PPC is larger than average, it will be valued as 1 , and it will be valued as 0 if it is less than one (Gani and Jermias 2006).

Hypothesis Testing Model

$$
\begin{gathered}
\text { STRA }=\gamma_{1} \mathrm{FAM}+\gamma_{2} \mathrm{AC}+\zeta, \\
\mathrm{KK}=\gamma_{1} \mathrm{FAM}+\gamma_{2} \mathrm{AC}+\gamma_{3} \mathrm{STRA}+\zeta,
\end{gathered}
$$

where: STRA - Business Strategy (Z); FAM - Family Ownership (X1); AC - Agency costs (X2); KK - Financial Performance $(\mathrm{Y}) ; \zeta$ - error in equation.

\subsection{Data analysis model}

The hypotheses were tested using partial least-square (PLS). PLS is a structural equation model (SEM) which is based on component or variance. According to Ghozali (2014), PLS is an alternative approach which shifts from covariance-based SEM to variance-based SEM. Covariance-based SEM usually tests causality or theory while PLS is more like a predictive model.

\subsection{Outer model}

Outer Model will explain three important components in elaborating relationship between indicator and its latent variable. The three components are (1) Convergent Validity, (2) Discriminant Validity, and (3) Composite Reliability.

\section{Results}

\subsection{Descriptive statistics}

The result of data processing for research data description can be seen in Table 1 .
The mean of Return on Asset $\left(\mathrm{Y}_{1}\right)$ is 4.868 percent with standard deviation of 7.960 percent. The mean of Return on Equity (Y2) is 10.488 percent with standard deviation of 76.649 percent. It indicates that there is a deviation of 76.649 percent of the average. It shows that the mean value is lower than the standard deviation. The mean of Family Ownership (X1) is 51.861 percent with standard deviation of 21.424 percent. It indicates that there is a deviation of 21.424 percent of the average. It shows that mean value is greater than the standard deviation, thus indicating larger deviation.

The next discussion is about business strategy data $(\mathrm{Z})$. About $46 \%$ of the companies tend to use differentiation or innovation while $54 \%$ of the companies tend to use low cost strategy.

The mean of Agency costs (X2) is 12.979 percent with a standard deviation of 11.859 percent. It indicates there is a deviation of 11859 percent of the average. It shows that mean value is greater than the standard deviation, thus indicating that the data do not deviate much from the average value.

\subsection{Results of Outer model testing}

\section{Convergent validity}

Convergent validity is observed from the correlation between item score and constructs score calculated by using PLS. The result of correlation between the item can be observed from the cross loading in Table 2 which shows that the value of cross loading between items is $>0.6$. This means that each question item is valid (Chin 1998).

Table 2. Result of analysis of Average Variance Extracted AVE and AVE Root

\begin{tabular}{|l|c|c|c|c|}
\hline & $\begin{array}{c}\text { Agency } \\
\text { Cost }\end{array}$ & $\begin{array}{c}\text { Family } \\
\text { Ownership }\end{array}$ & $\begin{array}{c}\text { Financial } \\
\text { Perfor- } \\
\text { mance }\end{array}$ & $\begin{array}{c}\text { Business } \\
\text { Strategy }\end{array}$ \\
\hline Agency Cost & 1.000 & & & \\
\hline $\begin{array}{l}\text { Family } \\
\text { Ownership }\end{array}$ & 0.0123 & 1.000 & & \\
\hline $\begin{array}{l}\text { Financial } \\
\text { Performance }\end{array}$ & -0.069 & 0.262 & 1.000 & \\
\hline $\begin{array}{l}\text { Business } \\
\text { Strategy }\end{array}$ & 0.461 & 0.077 & 0.410 & 1.000 \\
\hline
\end{tabular}

Table 1. Descriptive statistic of variables

\begin{tabular}{|l|c|c|c|c|c|}
\hline & ROA & ROE & FAM & PPC & AC \\
\hline Mean & 4.868 & 10.488 & 51.861 & 0.464 & 12.979 \\
\hline Median & 4.135 & 8.700 & 50.190 & 0.000 & 9.313 \\
\hline Maximum & 74.840 & 142.420 & 97.960 & 1.000 & 67.539 \\
\hline Minimum & -29.010 & -233.710 & 21.400 & 0.000 & -11.349 \\
\hline Std. Dev. & 7.960 & 76.649 & 21.424 & 0.499 & 11.859 \\
\hline
\end{tabular}

Note: ROA is Return on Asset, ROE is Return on Equity, FAM is Family Ownership, PPC is Premium Price Capability, AC is Average Cost. All variables are expressed in percentage. 


\section{Discriminant validity}

Discriminant validity is done to make sure that each concept of each latent variable is different from other variables. The model has good discriminant validity if each loading value from each indicator of a latent variable has the biggest loading value among other loading values of other latentc variables. Table 3 shows the value of AVE which is bigger than 0.5 while the AVE root is bigger than 0.7. The result of discriminant validity test can be seen in Table 3 .

It can be observed in the Table 3 that the AVE root for agency costs construct is 1.000 which is bigger than correlation between agency costs and family ownership which is 0.0128 . The correlation between agency costs and financial performance is -0.069 and the correlation between agency costs and business strategy (Table 4 ) is 0.460 . The AVE root for family ownership construct is 1.000 which is bigger than correlation between family ownership and financial performance which is 0.262 . The correlation between family ownership and business strategy is 0.077 . The AVE root for financial performance construct is 0.933 is bigger than correlation between financial performance and business

Table 3. The Result of Correlation Test between Constructs

\begin{tabular}{|l|c|c|c|c|}
\hline & $\begin{array}{c}\text { Agency } \\
\text { Costs }\end{array}$ & $\begin{array}{c}\text { Family } \\
\text { Ownership }\end{array}$ & $\begin{array}{c}\text { Financial } \\
\text { Perfor- } \\
\text { mance }\end{array}$ & $\begin{array}{c}\text { Business } \\
\text { Strategy }\end{array}$ \\
\hline Agency Cost & 1.000 & & & \\
\hline $\begin{array}{l}\text { Family } \\
\text { Ownership }\end{array}$ & 0.0123 & 1.000 & & \\
\hline $\begin{array}{l}\text { Financial } \\
\text { Performance }\end{array}$ & -0.069 & 0.262 & 1.000 & \\
\hline $\begin{array}{l}\text { Business } \\
\text { Strategy }\end{array}$ & 0.461 & 0.077 & 0.410 & 1.000 \\
\hline
\end{tabular}

Table 4. Results of Composite Reliability test

\begin{tabular}{|l|c|l|}
\hline \multicolumn{1}{|c|}{ Variables } & $\begin{array}{c}\text { Composite } \\
\text { Reliability }\end{array}$ & \multicolumn{1}{c|}{ Notes } \\
\hline Agency Cost & 1.000 & Reliable \\
\hline Family Ownership & 1.000 & Reliable \\
\hline Financial Performance & 0.871 & Reliable \\
\hline Business Strategy & 1.000 & Reliable \\
\hline
\end{tabular}

strategy which is 0.410 . The value of business strategy construct is 1.000000 which is bigger than the correlation between business strategy and agency costs which is 0.460983 . It can be concluded that the discriminant validity is fulfilled.

\section{Composite reliability}

The value of a construct is considered reliable if it shows composite reliability value of $>0.70$ (Werts et al. 1974). The result of reliability test is shown in Table 5 as follows:

The results of Composite Reliability test show that the value of composite reliability is bigger than 0.7 which indicates that all constructs or variables in this research are fit; it means all question items used to measure each construct are reliable. Table 6 shows the result of hypothesis testing. The first hypothesis proposes that family ownership influences business strategy. The test result shows that the first hypothesis is rejected $(\mathrm{t}$-value $=1.510, \mathrm{t}$-table $=1.960)$. It means family ownership does not influence business strategy. It shows that uniqueness and special characteristics of family company in selecting business strategy cannot explain certain business strategy which is suitable with family ownership. The findings of this research are identical with the findings of some studies by Ibrahim et al. (2008), and Lindow et al. (2010). On the contrary, Breton-Miller and Miller (2008) and Haque and Omotta (2001) find that a family company prefers diversification strategy.

The second hypothesis proposes that family ownership influences financial performance. The result of the second hypothesis testing can be seen in Table 6 which indicates relationship between family ownership and financial performance by the value of path coefficient which is 0.224 and $\mathrm{t}$-stat which is 6.540 . The value is bigger than the $\mathrm{t}$-table of 1.96. It indicates that family ownership influences financial performance. It means that family companies are able to improve their performance by collaborating five competitive advantages, namely combination of ownership and control, reduced information gap, sustainable family shareholders, source of entrepreneurship and innovations, and investment efficiency. Therefore, this approach can influence family ownership to the company's performance (Chu 2011). The findings of this research are identical with the findings or studies conducted by Astuti et al. (2015) and Warsini and Rossieta (2013). On the contrary, a research project by

Table 5. Hypothesis testing results

\begin{tabular}{|l|c|c|c|c|}
\hline \multicolumn{1}{|c|}{ Relationship } & $\begin{array}{c}\text { Sample Mean } \\
(\mathrm{M})\end{array}$ & $\begin{array}{c}\text { Standard Deviation } \\
(\text { STDEV })\end{array}$ & $\begin{array}{c}\text { Standard Error } \\
(\text { STERR })\end{array}$ & $\begin{array}{c}\mathrm{t} \text {-Statistics } \\
(|\mathrm{O} / \mathrm{STERR}|)\end{array}$ \\
\hline Family Ownership $\rightarrow$ Business Strategy & 0.072 & 0.047 & 0.047 & 1.510 \\
\hline Agency Cost $\rightarrow$ Financial Performance & -0.327 & 0.064 & 0.064 & 5.027 \\
\hline Agency Cost $\rightarrow$ Business Strategy & 0.458 & 0.037 & 0.037 & 12.198 \\
\hline Family Ownership $\rightarrow$ Financial Performance & 0.229 & 0.034 & 0.034 & 6.540 \\
\hline Business Strategy $\rightarrow$ Financial Performance & 0.546 & 0.032 & 0.032 & 16.443 \\
\hline
\end{tabular}


Table 6. Indirect effect of Sobel Test

\begin{tabular}{|l|c|c|c|c|c|c|c|}
\hline & $\mathrm{a}$ & $\mathrm{Sa}$ & $\mathrm{b}$ & $\mathrm{Sb}$ & $\mathrm{Ab}$ & $\mathrm{Sab}$ & $\mathrm{t}$ \\
\hline $\begin{array}{l}\text { Agency Cost } \rightarrow \text { Business Strategy } \rightarrow \text { Financial } \\
\text { Performance }\end{array}$ & -0.322 & 0.0640 & 0.541 & 0.032 & -0.174 & 0.036 & -4.799 \\
\hline $\begin{array}{l}\text { Family Ownership } \rightarrow \text { Business Strategy } \rightarrow \\
\text { Financial Performance }\end{array}$ & 0.224 & 0.0343 & 0.541 & 0.032 & 0.121 & 0.020 & 6.067 \\
\hline
\end{tabular}

Bae et al. (2012) found a decrease in stock price in familyconcentrated companies.

The third hypothesis proposes that agency costs influence business strategy. The result of the third hypothesis testing can be seen in Table 6 which indicates the relationship between agency costs variable and business strategy by the value of path coefficient which is 0.460 and $t$-stat of 12.199. The value is bigger than the $t$-table of 1.96 . It indicates that agency costs influence business strategy. It means that agency costs in a family company can be minimized if the company is under a good governance which controls the relationship between the owner and the management (Astuti et al. 2015). The company's ability to minimize the agency costs is beneficial for planning the business strategy. The findings of this research are identical with the results of studies by Ward and Handy (1988), Meyer and Zucker (1989). On the contrary, Powel states that minimizing agency costs does not mean that strategic planning is used as exogenous factor such as market competitiveness by which private companies compete.

The fourth hypothesis proposes that agency costs influence financial performance. The result of the fourth hypothesis testing can be seen in Table 6 which indicates the relationship between agency costs variable and financial performance by the value of path coefficient which is -0.322 and $t$-stat of 5.027. The value is bigger than the t-table of 1.96. It indicates that agency costs influence financial performance. It means that high agency costs indicate poor company management in managing operational expenses to gain operational profit and hints hidden managerial frauds in the use of operational expenses which raise the agency costs and decline the company performance. If a company is able to manage its assets efficiently, it will show that there is no managerial fault which influences the company performance (Layyinaturrobaniyah and Fitriyana 2014). This finding is identical with the findings of studies by Layyinaturrobaniyah and Fitriyana (2014) and Xiao (2009). On the contrary, Astuti et al. (2015) argues that in a company under family domination, mechanism to decrease agency problem is not suitable with reduction of agency costs so it will not influence the company performance.

The fifth hypothesis proposed in this research states that business strategy influences financial performance. The result of the fifth hypothesis testing can be seen in Table 6 which indicates the relationship between business strategy and financial performance by the value of path coefficient of 0.541 and $t$-stat of 16.443 . The value is bigger than the $t$-table of 1.96. It indicates that business strategy influences financial performance. It means that the tendency in selecting business strategy will give benefit to financial performance of the company. Selecting the right strategy is able to improve company performance and boost superior performance for the company organization. Strategy selection is also able to put value for the customers and create competitive advantages for the company (Porter 1980). This result is identical with studies by Warsini and Rossieta (2013), and Moores (2009). On the contrary, research projects by Lindow et al. (2010) cannot prove strategy of family companies and cannot obtain conclusive result about financial performance.

Indirect hypothesis testing is conducted by using Sobel formula. The result of Sobel Formula can be seen in Table 6 .

The sixth hypothesis proposed in this research is that the indirect influence of business strategy to family ownership influences financial performance. The mediation testing shows that the value of path coefficient is 0.541 and $t$-stat is -4.799 . It is bigger than $\mathrm{t}$-table which is 1.96 It indicates that business strategy is able to influence relationship between family ownership and financial performance. It means that family companies do not only aim for financial goal but also the sustainability of the company so that the business strategy can be fulfilled and influence the financial performance (Moores 2009). This result is identical with research findings of studies by Lena (2007) and Moores (2009). On the contrary, Lindow et al. (2010) state that business strategy does not give conclusive result of family ownership to financial performance.

The seventh hypothesis proposed in this research is that there is indirect influence of business strategy to agency costs which influence financial performance. The mediation testing shows that the value of path coefficient is 0.541 and $\mathrm{t}$-stat is 6.067. It is bigger than $\mathrm{t}$-table which is 1.96 . It indicates that business strategy is able to influence relationship between agency costs and financial performance. It means that the fund which is meant to be allocated for agency costs can be distributed to business strategy planning which supports the company development (Lindow et al. 2010). This result is identical with studies by Jensen and Meckling (1976) and Ward and Handy (1988). On the contrary, Powell (1992) states that the use of strategy does not influence financial performance. 


\section{Conclusions and futher study}

Family-concentrated companies do not influence business strategy used by the companies since uniqueness and company characteristics are important in applying the strategy. Family ownership influences company financial performance because a family company can increase its performance by collaborating five competitive advantages. Control rights motivate family ownership to supervise the company. Agency costs influence business strategy. It shows that companies are able to minimize the agency costs and distribute the fund for planning the company business strategy. Agency costs influence financial performance which shows that agency costs contribute to the increase and decrease of financial performance. If the agency costs are high, the company will lower the financial performance and vice versa. Business strategy influences financial performance. It indicates that the selection of business strategy will determine the company performance. The business strategy is able to influence relationship between family ownership and financial performance. It shows that family companies do not aim for financial goal but also for sustainability. Business strategy influences the relationship between agency costs and financial performance. It shows that the fund can be distributed to business strategy planning which will improve the company development.

This study has limitation: Company with minimum family ownership of $20 \%$ would prefer to raise alignment beetween owners and management so that improving company performance. The company would choose the right business strategy and agency cost in improving its financial performance and would not only concern with profit, but also reach market share, improve its performance and competitive advantage. And also try to always improve its performance and competitive advantage.

Based on the conclusions, two issues merit to be addressed for future study. Future study may retest the proxy and differences that can be used to measure the performance of companies. Future study may also consider to develop the research in agribusiness industries, mining and non-manufacturing sectors. Subsequent research which focus on family-concentrated companies should consider the family controls over the company that can cause agency problems within the company and affect the financial performance.

\section{References}

Anderson RC, Reeb DM (2003) Founding-family ownership and firm performance: evidence from the S\&P 500. Journal of Finance 58 (3): 1301-1328. https://doi.org/10.1111/15406261.00567

Ang J, Cole S, Rebel A, Wuh LJ (2000) Agency costs and ownership structure. Journal of Finance 55 (1): 81-106. https://doi. org/10.1111/0022-1082.00201
Anggraita V (2013) The effect of moderation on the relationship between corporate strategy and corporate performance monitoring mechanism. Simposium Nasional Akuntansi: 5062-5087.

Astuti AD, Rahman, Sudarno (2015) The influence of family ownership of the company's financial performance with the agency costs as a moderating variable in Indonesian. Jurnal Dinamika Akuntansi 7 (2): 98-108.

Bae KH, Jae SB, Jun KK, Wei LL (2012) Do controlling shareholders expropriation incentives imply a link between corporate governance and firm value? Theory and evidence. Journal of Financial Economics 105: 412-435. https://doi.org/10.1016/j. jineco.2012.02.007

Breton-Miller I, Miller D (2008) Why do some family businesses out compete?: governance, long term orientation and sustainable capability. Entrepreneurship Theory and Practice 30: 731-746. https://doi.org/10.1111/j.1540-6520.2006.00147.x

Chin WW (1998) The partial least squares approach to structural equation modeling. In: Marcoulides GA (Ed) Modern methods for business research. Erlbaum, Mahwah, 295-358.

Chu W (2011) Family ownership and firms performance: influence of family management, family control and firm size. Asia Pacific Journal Management 28 (4): 833-851. https://doi. org/10.1007/s10490-009-9180-1

Claessens S, Dajnkov S, Lang HP (2000) The separation of ownership in East Asia corporation. Journal of Finance Economics 58 (1-2): 81-112. https://doi.org/10.1016/S0304-405X(00)00067-2

David FR (2011) Management strategy: concept and cases. New Jersey: Prentice Hall International.

Donaldson L, Davis JH (1991) Stewardship theory or agency theory: CEO governance and shareholder returns. Australian Journal of Management 16 (1): 49-64. https://doi. org/10.1177/031289629101600103

Faccio M, Lang LH (2002) The ultimate ownership of Western European corporations. Journal of Financial Economics 65 (3): 365-395. https://doi.org/10.1016/S0304-405X(02)00146-0

Faisal (2005) Analysis of agency costs, ownership structure and corporate governance mechanism In Indonesian. Jurnal Riset Akuntansi 8 (2): 175-190.

Fama EF, Jensen MC (1983) Separation of ownership and control. European Journal of Law and Economics 26: 301-325. https:// doi.org/10.1086/467037

Gani L, Jermias J (2006) Investigating the effect of board independence on performance across different strategies. The International Journal of Accounting 41: 295-314. https://doi.org/10.1016/j. intacc.2006.07.009

Ghozali I (2014) Structural equation modeling: alternative method with partial least square (4th ed). Semarang: Diponegoro University.

Haque A, Omotta H (2001) Strategic marketing practice considerations in family business in Bangladesh. New England Journal of Enterpreneurship 42: 102-111.

Haryadi B (2008) Strategic alignment between business strategy and information systems strategy. Telaah Manajemen 33: 127-144.

Ibrahim NA, Angelidis JP, Parsa F (2008) Strategic management of family business: current findings and directions for future research. International Journal of Management 25: 95-110. 
Jensen MC, Meckling WH (1976) Theory of the firms: managerial behavior, agency costs and ownership structure. Journal of financial and economic 3 (4) 305-360. https://doi. org/10.1016/0304-405X(76)90026-X

La Porta R, Lopez-de-Silanes F, Shleifer A (1999) Corporate ownership around the world. Journal of Finance 54 (2): 471-517. https://doi.org/10.1111/0022-1082.00115

Lamin A (2007) The Effect of business group affiliation on firms strategy. Disertation, University of Minnesota.

Layyinaturrobaniyah R, Fitriyana D (2014) The agency costs of family and non family firms. Siasat Bisnis 18 (2): 169-179. https://doi.org/10.20885/jsb.vol18.iss2.art3

Lena (2007) Alignment technology operations strategy and corporate performance: an exploration study on manufacturing company in Indonesia. Usahawan 36: 43-55.

Lindow CM, Stubner S, Waft T (2010) Strategic fit within family firms: the role of family influence and the effect on performance. Journal of Family Business Strategy 1: 167-178. https:// doi.org/10.1016/j.jfbs.2010.08.004

Litz RA, Crewman JJ, Chua JH (2004) Comparing the agency costs of family and non family firms: conceptual and exploratory evidence. Enterpreneurship Theory and Practice 28 (4): 335354. https://doi.org/10.1111/j.1540-6520.2004.00049.x

Madison KJ (2014) Agency theory and stewardship theory integrated, expanded, and bounded by context: an empirical investigation of structure, behavior, and performance within family firms. Doctoral Dissertation, University of Tennessee.

Meyer M, Zucker LG (1989) Permanently failing organizations. Newbury Park: Sage.

Moores K (2009) Paradigms and theory building in the domain of business families. Family Business Review 22: 167-180. https://doi.org/10.1177/089448650933337

Morck R, Yeung B (2004) Family control and the rent-seeking society-etrepreneurship. Family Business Review 22: 167-180.

Porter ME (1980) Competitive strategy: techniques for analyzing industries and competitors. New York: Free Press.
Poza EJ, Alfred T, Maheswari A (1997) Stakeholders perception of culture and management practices in family firms a-premelinery report. Family Business Review (10): 135-155. https:// doi.org/10.1111/j.1741-6248.1997.00135.x

Powell TC (1992) Strategic planning as competitive advantage. Strategic Management 13: 551-558. https://doi.org/10.1002/ smj.4250130707

Sawir A (2005) Financial performance analysis and financial planning company. Jakarta: Gramedia Pustaka.

SFAS 15 (2013) Statement of Financial Accounting Standards 15 concerning Investments in Associates and Venture Parties, par 5 and 6.

Shyu J (2011) Family ownership and firm performance: evidence from Taiwanese Firms. International Journal of Managerial Finance 7 (4): 397-411. https://doi. org/10.1108/17439131111166393

Villalonga B, Amit R (2006) How do family ownership, control and management affect firm value? Journal of Finance Economics 80: 385-417. https://doi.org/10.1016/j.jfineco.2004.12.005

Ward JL, Handy JL (1988) A survey of board practices. Family Business Review 1 (3): 298-308. https://doi.org/10.1111/j.17416248.1988.00289.x

Warsini S, Rossieta H (2013) The Influence of family ownership on corporate performance taking into account the business strategy as moderating variable (Study on Indonesia Stock Exchange). Proceeding Simposium Nasional Akuntansi XVI, Manado.

Werts CE, Linn RL, Joreskog KG (1974) Intraclass reliability estimates: Testing structural assumptions. Educational and Psychological Measurement 34 (1): 25-33. https://doi. org/10.1177/001316447403400104

Wiranata, Nugrahanti (2013) Effect of ownership structure on profitability in Indonesia. Jurnal Akuntansi Keuangan 15 (1): 15-26.

Xiao S (2009) How does agency costs affect firm value? Evidence from China. Journal of Economic Literature 30 (10): 11131132. 